\title{
MUSIK LANGGAM JAWA TERHADAP KECEMASAN PADA PASIEN PRE SECTIO CESAREA
}

\author{
Siti Sadiah $^{1 *}$, Happy Dwi Aprilina² \\ ${ }^{1,2}$ Fakultas Ilmu Kesehatan Program Studi Sarjana Keperawatan \\ Universitas Muhammadiyah Purwokerto 2020 \\ Dusun II, Sokaraja Kulon, Kec. Sokaraja, Kabupaten Banyumas, Jawa Tengah 53181 \\ sitisadiah533@gmail.com
}

\begin{abstract}
Abstrak
Persalinan sesarea atau sectio ceaserea (SC) merupakan proses pembedahan untuk melahirkan janin melalui irisan pada dinding perut dan dinding uterus. Tindakan ini secara umum menyebabkan rasa cemas pada ibu yang akan menjalani persalinan. Tujuan: mengetahui pengaruh musik langgam jawa terhadap kecemasan pada pasien pre sectio caesarea. Penelitian ini menggunakan desain pre experimental with one grup pre and posttest without control grup design. Penelitian menggunakan teknik Accidental sampling sebanyak $46 \mathrm{ibu}$. Analisis data dengan uji paired $t$ test. Responden sebagian besar umur responden dalam kategori tidak beresiko sebanyak 39 responden $(84,8 \%)$, pendidikan menengah sebanyak 21 responden (45,7\%), pekerjaan sebagai ibu rumah tangga sebanyak 21 responden $(76,1 \%)$ dan paritas paritas sebanyak 27 responden $(58,7 \%)$. Kecemasan pasien sebelum diberikan musik lenggam jawa rata-rata 19,04 dengan standar deviasi 3,25 sedangkan sesudah rata-rata 11,83 dengan standar deviasi 2,93. Hasil uji statistic diperoleh p value $<0,05$ artinya ada pengaruh musik langgam jawa terhadap kecemasan pada pasien pre sectio caesarea $p$ value 0,000 . Terdapat pengaruh musik langgam jawa terhadap kecemasan pada pasien pre sectio caesarea di RSUD Banyumas dengan $p$ value 0.000. Musik lenggam jawa dapat menjadi pengatur suasana hati yang kuat yang dapat menyebabkan relaksasi dan mengurangi kecemasan ibu pre SC.
\end{abstract}

Kata Kunci: langgam jawa, kecemasan, pre sectio caesarea

\begin{abstract}
Caesarean delivery or sectio ceaserea (SC) is a surgical process to give birth to a fetus through incisions in the abdominal and uterine walls. This action generally causes anxiety in mothers who will undergo childbirth. Objective: Knowing the effect of Javanese Langgam music on anxiety in pre-sectio caesarea patients. A pre-experimental design with one group pre and posttes without control group design. The study used 46 accidental sampling techniques. Data analysis with paired t test. 39 respondents $(84,8 \%)$ were not in the category of risky ages, 21 respondents $(45,7 \%)$ were secondary graduates, 21 respondents $(76,1 \%)$ were housewives, and 27 respondents $(58,7 \%)$ were primipara parity. The average patient's anxiety was 19,04 with a standard deviation of 3,25 before Javanese Langgam style music and it was 11,83 with a standard deviation of 2,93 qfter the treatment. Based on the statistical test result, it obtained p-value 0.05, there is an effect of Javanese music style a ward the anxiety in patiens with pre section caesarea p-value 0.000. Conclusion: Javanese Langgam music effect on anxiety in pre-sectio caesarea patients in Banyumas Regional Hospital with p-value 0.000. Hand music can be a powerful mood regulator that can cause relaxation and reduce maternal anxiety pre CS.
\end{abstract}

Keywords: Javanese style, anxiety, pre sectio caesarea

Corresponding author:

Siti Sadiah

sitisadiah533@gmail.com 


\section{PENDAHULUAN}

Angka tindakan sectio cesarea di RSUD Banyumas tahun 2018 sebanyak $678 \mathrm{ibu}$ $(19,45 \%)$ (Data Rekam Medis, 2019). Tindakan operasi cesarea menurut Pratiwi (2015) merupakan salah satu bagian dari tindakan medis dalam menyelamatkan nyawa ibu dan janin. Operasi cesarea dilakukan dengan alasan karena gawat janin, diproporsi sepalopelvik, panggul sempit, prolapsus tali pusat, malpresentasi janin, persalinan tidak maju dan plasenta previa.

Secara umum tindakan operasi bagi pasien adalah sesuatu hal yang tidak diinginkan karena bagi mereka tindakan tersebut sangat menakutkan. Tindakan operasi menurut Paryanto (2009) dapat memberikan pengalaman yang menimbulkan perasaan cemas bagi pasien. Kondisi tersebut dapat memberikan berbagai kemungkinan buruk yang akan membahayakan pasien. Perasaan cemas yang timbul pada pasien berhubungan dengan segala macam prosedur asing yang harus dijalani pasien dan memiliki dampak terhadap ancaman keselamatan jiwa atau kematian.

Hasmawa (2016) menjelaskan bahwa kecemasan pre operasi timbul pada saat pasien memiliki persepsi dan pemahaman yang kurang menyenangkan pada tindakan operasi itu sendiri. Kecemasan tersebut muncul karena pasien memiliki persepsi terhadap tindakan operasi seperti: kematian, kecacatan, rasa sakit saat atau setelah operasi, dan kegagalan operasi. Menurut Triatna (2018) menjelaskan bahwa respon paling umum pada pasien pre-operasi salah satunya adalah kecemasan. Ada beberapa cara untuk mengurangi kecemasan, salah satunya adalah dengan pemberian terapi musik. Musik Langgam Jawa dapat mengurangi kecemasan pada pasien pre operasi.

Jones (2011) menyatakan bahwa musik merupakan salah satu terapi yang aman, ekonomis, mudah, dan efektif dalam menghilangkannya kecemasan pre operasi dan memberikan relaksasi untuk pasien yang menunggu operasi. Hasil penelitian Daryani (2012) menunjukkan bahwa skor tingkat kecemasan pasien pre intervensi skor terendah 23 dan tertinggi 55 sedangkan post intervensi skor terendah 7 dan skor tertinggi 33. Tingkat kecemasan pre intervensi dengan skor rata-rata $34,82 \pm 10,754$ sedangkan post $18,12 \pm 7,236$. Musik langgam jawa yang diberikan yaitu lagulagu Jawa yang dinyanyikan oleh Waljinah dengan berdurasi 4-5 menit melalui headset. Kondisi lingkungan pada saat intervensi disetting sesuai dengan kemauan responden.

Berdasarkan hasil pra survey didapatkan data bahwa pada tahun 2018 jumlah persalinan sebanyak 3485 ibu. Dari angka tersebut persalinan paling banyak adalah persalinan secara spontan sebanyak $2506 \mathrm{ibu}$ (71,9\%), kedua sectio cesarea sebanyak 678 ibu $(19,45 \%)$ dan ketiga secara tindakan sebanyak $301 \mathrm{ibu}(8,6 \%)$. Indikasi sectio caesarea paling tinggi dengan alasan adalah riwayat SC dan yang kedua adalah gemeli. Peneliti juga melakukan wawancara terhadap 10 ibu didapatkan bahwa ada 8 ibu yang merasa cemas dan takut akan dilakukan tindakan operasi SC sedangkan 2 ibu biasa akan dilakukan operasi karena baginya sebelumnya sudah menjalani operasi yang sama. Peneliti juga memberikan suatu intervensi berupa musik langgam jawa yang dibawakan oleh Didi Kempot dan Waljinah terhadap 10 pasien. Hasil pengukuran diperoleh bahwa ada 6 pasien menyukai musik yang dibawakan oleh Didi Kempot, sedangkan 4 pasien menyukai musik yang dibawakan oleh Waljinah.

Penelitian ini memiliki tujuan mengetahui pengaruh musik langgam jawa terhadap kecemasan pada pasien pre sectio caesarea.

\section{METODE PENELITIAN}

Desain penelitian menggunakan pre experimental with one grup pre and posttest without control grup design. Sampel yang digunakan adalah 46 ibu dengan teknik accidental sampling sebanyak 46 ibu. Analisis data dengan paired t test. 


\section{HASIL}

Tabel 1 Karakteristik Responden (Umur, Pendidikan Dan Paritas) Jawa Pasien Pre Sectio Caesarea di RSUD Banyumas (N = 46).

\begin{tabular}{|c|c|c|}
\hline Karakterstik & $\mathrm{F}$ & $\%$ \\
\hline \multicolumn{3}{|l|}{ Umur } \\
\hline - Tidak beresiko & 39 & 84.8 \\
\hline Beresiko & 7 & 15.2 \\
\hline \multicolumn{3}{|l|}{ Pendidikan } \\
\hline - Rendah & 18 & 39.1 \\
\hline - Menengah & 21 & 45.7 \\
\hline - $\quad$ Tinggi & 7 & 15.2 \\
\hline \multicolumn{3}{|l|}{ Pekerjaan } \\
\hline $\begin{array}{l}\text { - Ibu rumah } \\
\text { tangga }\end{array}$ & 35 & 76.1 \\
\hline - $\quad$ Swasta & 11 & 23.9 \\
\hline \multicolumn{3}{|l|}{ Paritas } \\
\hline - Primipara & 27 & 58.7 \\
\hline Multipara & 19 & 41.3 \\
\hline \multicolumn{3}{|c|}{$\begin{array}{l}\text { Tabel } 1 \text { menunjukkan karakteristik } \\
\text { responden berdasarkan umur sebagian besar } \\
\text { tidak beresiko sebanyak } 84,8 \% \text { dangan tingkat } \\
\text { pendidikan paling banyak menengah sebanyak } \\
\text { Tabel } 3 \text { menunjukkan bahwa terdapat } \\
\text { pengaruh musik langgam jawa pada pasien pre } \\
\text { section caesarea dengan } p \text { value }=0,000 \text {. }\end{array}$} \\
\hline
\end{tabular}

\section{PEMBAHASAN}

1. Karakteristik ibu berdasarkan umur, pendidikan dan paritas.

a. Umur

Hasil penelitian yang telah dilakukan menunjukkan bahwa umur responden sebagian besar dalam kategori tidak beresiko sebanyak 39 $(84,8 \%)$. Umur seorang ibu berperan penting dalam keselamatan ibu hamil dan bayi yang dikandungannya. Menurut Sibuea (2013) bahwa usia < 20 maupun $\geq 35$ tahun memiliki risiko pada saat persalinan. Persalinan pada usia tersebut akan lebih lama dan adanya penyulit pada saat melahirkan. Selain itu, bayi lahir mati juga sering ditemukan pada kehamilan dan persalinan dengan usia ibu $<20$ ataupun $\geq 35$ tahun

Kesehatan seorang ibu dan janin ditentukan oleh usia ibu sendiri. Menurut Sianturi (2007) dalam Monita
45,7\% dan Sebagian besar bekerja sebagai ibu rumah tangga sebanyak $76,1 \%$ serta sebagian termasuk primipara sebanyak $58,7 \%$.

Tabel 2 Kecemasan Pre Dan Post Intervensi Musik Langgam Jawa Pasien Pre Sectio Caesarea di RSUD Banyumas $(\mathrm{N}=46)$.

\begin{tabular}{|c|c|c|}
\hline Kecemasan & Mean \pm SD & $\begin{array}{l}\text { Minimal- } \\
\text { Maksimal }\end{array}$ \\
\hline - Pre & $19,04+3,25$ & $11-25$ \\
\hline - Post & $11,83+2,93$ & $5-20$ \\
\hline
\end{tabular}

Tabel 2 didapatkan kecemasan sebelum diberikan intervensi musik langgam jawa pada pasien pre section caesarea rata-rata 19,04 dan setelah diberikan intervensi mengalami penurunan kecemasan dengan nilai rata-rata 11,83 .

Tabel 3 Pengaruh musik langgam jawa terhadap kecemasan pada pasien pre sectio caesarea di RSUD Banyumas ( $N=46)$.

\begin{tabular}{ccc}
\hline Kecemasan & Mean \pm SD & P value \\
\hline Pre & $19.04 \pm 3.25$ & 0.000 \\
Post & $11.83 \pm 2.93$ & \\
\hline
\end{tabular}

(2016) bahwa usia hamil yang beresiko tinggi $(<20$ ataupun $\geq 35$ tahun) adalah salah satu faktor yang menyebabkan BBLR. Usia reproduksi yang baik atau resiko rendah bagi ibu yang ingin hamil adalah usia 20-35 tahun, sedangkan usia dibawah dan diatas usia tersebut akan meningkatkan risiko pada saat hamil ataupun melahirkan.

Sedangkan menurut Trianingsih (2015) dalam penelitiannya menjelaskan bahwa usia aman bagi seorang ibu untuk hamil dan melahirkan yaitu 20-35 tahun. Seorang ibu dengan usia $<20$ tahun organ reproduksi seperti jaringan endometrium belum siap untuk melakukan proses kehamilan. Ketidaksiapan organ reproduksi salah satunya berdampak pada jaringan plasenta yang akan memperlebar diri dalam memenuhi kebutuhan nutrisi janin, yang nantinya menutupi seluruh maupun sebagian ostium uteri internum. Sedangkan pada usia lebih dari 35 tahun ibu hamil berisiko mengalami plasenta previa yang dikarenakan terjadinya kemunduran 
fungsi fisiologi dan reproduksi yang disebabkan karena terjadi sklerosis pembuluh darah arteri kecil dan arteriol myometrium. Kondisi tersebut menyebabkan aliran darah ke endometrium tidak merata yang pada akhirnya endometrium menjadi kurang subur.

b. Pendidikan

Hasil penelitian yang telah dilakukan menunjukkan bahwa tingkat pendidikan paling banyak menengah sebanyak 21 responden $(45,7 \%)$. Pendidikan yang ditempuh seseorang adalah faktor yang berperan penting dalam memperkuat tingkat pengetahuannya. Pengetahuan yang baik tentang masalah kesehatan akan memberikan pemahaman yang baik terhadap tindakan keperawatan khususnya tindakan SC. Fajrin (2009) menjelaskan bahwa pendidikan seorang ibu adalah bagian yang penting dapat mendukung perilaku ibu pada upaya deteksi dini komplikasi kehamilan dan persalinan. Ibu yang memiliki tingkat pendidikan tinggi akan lebih baik dalam memperoleh informasi tentang kesehatan jika dibandingkan ibu dengan tingkat pendidikan rendah.

Menurut Purwatmoko (2001) dalam Sari (2017) bahwa semakin tinggi tingkat pendidikan seseorang semakin besar peluang untuk mencari pengobatan ke pelayanan kesehatan. Tingkat pendidikan yang cukup akan memudahkan dalam mengidentifikasi stressor dalam diri sendiri maupun dari luar dirinya. Tingkat pendidikan yang rendah berpengaruh terhadap ketakutan primipara dalam menghadapi proses persalinan.

c. Pekerjaan
Hasil penelitian yang telah dilakukan menunjukkan bahwa pekerjaan ibu sebagian besar adalah ibu rumah tangga sebanyak $21(76,1 \%)$. Ibu dalam penelitian ini sebagian besar fokus dalam mengurus keperluan rumah tangga dan mengasuh anaknya. Hal ini sering menyebabkan ibu dengan status sebagai ibu rumah tangga kurang dalam menyerap ilmu pengetahuan terkait dengan masalah kesehatan,

sehingga ketika mengalami masalah kesehatan cenderung mudah cemas. Laursen et al. (2008) dalam dalam Sari (2017) hasil penelitiannya menjelaskan bahwa ibu yang tidak bekerja dengan kehamilan promipara cenderung mengalami ketakutan dalam menghadapi proses melahirkan.

Fajrin (2009) menjelaskan bahwa pekerjaan yang dijalani seorang ibu hamil memiliki faktor risiko terjadinya komplikasi persalinan. Pekerjaan yang dilakukan ibu dengan tujuan untuk terpenuhinya semua kebutuhan seharihari. Jenis pekerjaan yang dikerjaan seorang akan berdampak dalam mengakses berbagai informasi, khsususnya tentang kesehatan. Namun demikian, ibu hamil yang bekerja terlalu berat tanpa menjaga kesehatannya dengan mengkonsumsi makan yang sehat dapat meningkatkan risiko kematian ibu ataupun janin pada persalinan.

d. Paritas

Hasil penelitian yang telah dilakukan menunjukkan bahwa paritas responden sebagian besar primpipara sebanyak $27 \quad(58,7 \%)$. Paritas merupakan banyaknya bayi yang hidup dimiliki oleh ibu. Kehamilan yang baik adalah kehamilan yang memiliki jarang dengan kehamilan sebelumnya. Kehamilan yang optimal yaitu memiliki jarak > 36 bulan dari kehamilan sebelumnya (Varney, 2007).

Kehamilan dengan jarak yang terlalu dekat $(<2$ tahun) akan mengurangi manfaat dari kehamilan sebelumnya, misalnya uterus sudah membesar serta meningkatnya aliran darah menuju uterus. Begitu juga sebaliknya jika terlalu pendek jaraknya akan menyebabkan ibu tidak mempunyai waktu pemulihan, serta gangguan sistem reproduksi maupun masalah postpartum (Prawihardjo, 2009). Hasil penelitian Anita (2017) menunjukkan bahwa paritas paling aman adalah paritas 2-3, apabila dilihat dari aspek risiko kematian maternal. Sedangkan ibu dengan paritas 1 maupun >3 bahkan lebih memiliki 
risiko angka kematian maternal lebih besar.

2. Kecemasan pre dan post intervensi musik langgam jawa pada pasien pre sectio caesarea di RSUD Banyumas.

Hasil penelitian yang telah dilakukan menunjukkan bahwa rata-rata kecemasan ibu sebelum diberikan musik lenggam jawa sebesar 19,04 dengan standar deviasi 3,25 dan skor maksimal 11 sedangkan maksimal 25. Tingkat kecemasan pasien sebelum diberikan musik lenggam jawa dalam kategori ringan. Akan tetapi, pada saat penelitian berlangsung dalam penelitian ini juga ditemukan responden dengan tingkat kecemasan sedang. Pasien sebagian besar merasa tidak tenang, denyut nadi terasa cepat dan jantung berdetak lebih cepat. Hal tersebut karena bagi sebagian responden tindakan operasi SC adalah pengalaman pertama sehingga dalam diri mereka belum ada kesiapan untuk menjalaninya.

Menurut Hawari (2008), gejala klinik kecemasan pada pasien yaitu semas, khawatir, tegang, tidak tenang, gelisah dan mudah terkejut. Selain itu, keluhan somestik, seperti berdebar-debar sesak nafas, rasa sakit pada tulang maupun otot, pendengaran berdenging, sakit kepala, gangguan pencernaan dan perkemihan. Fazrin dan Saputro (2017) menambahkan bahwa pasien dengan kecemasan akan memunculkan respon perilaku seperti gelisah, tremor, ketegangan fisik, bicara cepat, reaksi terkejut, dan gangguan koordinasi.

Sedangkan hasil penelitian setelah diberikan musik lenggam jawa menunjukkan bahwa rata-rata kecemasan pasien sebesar 11,83 dengan standar deviasi 2,93 dan skor maksimal 5 sedangkan maksimal 20. Hasil tersebut menjelaskan bahwa pasien setelah diberikan musik lenggam jawa menunjukkan adanya penurunan tingkat kecemasan, dimana kategori kecemasan pasien merasa tidak cemas. Pasien tampak tenang dan rileks setelah diberikan musik lenggam jawa.

Hasil penelitian Ismail (2011) menunjukkan bahwa musik membawa perubahan yang bermanfaat dalam kesehatan emosi dan fisik pasien, dan memiliki kemampuan untuk memberikan perubahan keadaan fisik dan perubahan suasana hati setelah perubahan dengan memproses progresi not musik dengan nada, irama, dan instrumentasi yang berbeda untuk menyenangkan. efek. Hal tersebut didukung hasil penelitian Setyawan (2013) bahwa menunjukkan bahwa $76 \%$ perawatan standar ruangan yang dikombinasikan dengan terapi musik lebih efektif menurunkan tingkat kecemasan.

Tindakan operasi SC bagi pasien yang belum memiliki pengalaman cenderung memiliki dampak negatif yaitu pasien merasa cemas. Hal ini karena bagi pasien yang belum pernah mendapatkan informasi terkait dengan tindakan SC merupakan sesuatu yang sangat menakutkan. Selama penelitian berlangsung sebagian besar ditemukan kecemasan pasien dalam kategori ringansedang. Setelah pemberian intervensi tingkat kecemasan pasien mengalami penurunan. Penelitian Schall et. al. (2018) menjelaskan bahwa musik selama operasi caesar adalah cara yang mudah diimplementasikan dan efektif untuk mengurangi stres dan kecemasan ibu hamil.

\section{Pengaruh musik langgam jawa terhadap kecemasan pada pasien pre sectio caesarea}

Hasil analisis menunjukkan uji t paired $\mathrm{t}$ test diperoleh $p$ value 0,000 , artinya ada pengaruh musik langgam jawa terhadap kecemasan pada pasien pre sectio caesarea. Musik dapat dijadikan sebagai media terapi non farmakologi untuk mengobati permasalahan psikologis pasien khususnya pasien yang akan menjalani operasi SC. Pasien yang akan menjalani operasi secara umum mengalami rasa cemas yang dikarenakan takut akan efek samping dari tindakan operasi. Hasil penelitian didukung penelitian Triatna (2018) bahwa ada pengaruh yang signifikan dari "langgam jawa dengan kecemasan pasien pre operasi.

Hasil penuturan pasien pada saat mendengarkan musik lenggam jawa mereka merasa rileks dan tenang. Menurut 
Mirna (2014) bahwa kerja musik sebagai rileksasi melalui rangsangan atau unsur irama dan nada yang masuk ke canalis auditorius kemudian disalurkan ke thalamus sehingga memori di sistem limbik aktif secara otomatis. Setelah proses tersebut akan mempengaruhi saraf otonom yang kemudian disampaikan ke thalamus dan kelenjar hipofisis, pada akhirnya akan memunculkan respon terhadap emosional melalui feedback ke kelenjar adrenal untuk menekan pengeluaran hormon stress. Penekanan pengeluaran hormon stress menyebakan seseorang menjadi rileks dan tenang.

Musik lenggam jawa yang diberikan oleh peneliti terhadap pasien yang akan menjalani SC terbukti efektif dalam menurunkan tingkat nyeri. Hal ini dibuktikan dari penurunan skor kecemasan pasien, dimana secara langsung pasien tampak merasa lebih enak jika dibandingkan sebelum diberikan musik. Musik adalah pengatur suasana hati yang kuat yang dapat menyebabkan relaksasi dan mengurangi kecemasan dalam situasi yang berbeda.

\section{KESIMPULAN}

1. Responden sebagian besar umur responden dalam kategori tidak beresiko, pendidikan menengah, pekerjaan sebagai ibu rumah tangga, dan paritas primipara.

2. Kecemasan pasien sebelum diberikan musik lenggam jawa rata-rata kategori cemas ringan.

3. Kecemasan pasien sesudah diberikan musik lenggam jawa rata-rata tidak cemas.

4. Ada pengaruh musik langgam jawa terhadap tingkat kecemasan pada pasien pre sectio caesarea

\section{DAFTAR PUSTAKA}

Anita. (2017). Hubungan Paritas dan Riwayat Sectio Cesarea Dengan Kejadian Placenta Previa Di RSUD Arifin Achmad Pekanbaru. Journal Endurance 2(1).

Daryani. (2012). Pengaruh Terapi Musik Langgam Jawa Terhadap Penurunan Tingkat Kecemasan Pada Lansia Di
Purworejo. Artikel Ilmiah. Stikes Muhammadiyah Klaten.

Data Rekam Medis. (2019). Profil Kesehatan Tahun 2018. RSUD Banyumas.

Fajrin. (2009). Faktor-Faktor Yang Berhubungan Dengan Kejadian Komplikasi Persalinan Di Rumah Sakit Roemani Kota Semarang Tahun 2008. Skripsi. Universitas Negeri Semarang.

Fazrin dan Saputro. (2017). Anak Sakit Wajib Bermain di Rumah Sakit: Penerapan Terapi Bermain Anak Sakit, Proses, Manfaat dan Penatalaksanaanya. Jarkata: Forikes.

Hasmawa. (2016). Identifikasi Tingkat Kecemasan Pada Pasien Pre Operasi Di Rumah Sakit Umum Bahteramas Sulawesi Tenggara. Karya Tulis Ilmiah. Politeknik Kesehatan Kendari.

Hawari. D. (2008). Menejemen stres, Cemas, dan Depresi, Jakarta, Balai penerbit FK UI.

Ismail. (2011). Music and Music Intervention for Therapeutic Purposes in Patients with Ventilator Support; Gamelan Music Perspective. Nurse Media Journal of Nursing, 1 (1).

Jones. (2011). Use of Music to Minimize Preoperative Patient Anxiety. Music Therapy for Preoperative Anxiety. Texas Christian University

Mirna P. R. (2014). Pengaruh Terapi Musik Instrumental Dan Aromatherapy Lavender Eyemask Terhadap Penurunan Tingkat Insomnia Pada Mahasiswa Fisioterapi D3 Angkatan 2011. Naskah Publikasi. Surakarta: FIK UNS.

Monita. (2016). Hubungan Usia, Jarak Kelahiran Dan Kadar Hemoglobin Ibu Hamil Dengan Kejadian Berat Bayi Lahir Rendah Di RSUD Arifin Achmad Provinsi Riau. Jom FK, 3 (1).

Paryanto. (2009). Perbedaan Tingkat Kecemasan Pasien Pre Operatif Selama Menunggu Jam Operasi Antara Ruang Rawat Inap Dengan Ruang Persiapan Operasi Rumah Sakit Ortopedi Surakarta. Skripsi. Universitas Muhammadiyah Surakarta.

Sari. (2017). Pengaruh Pendidikan Kesehatan Terhadap Kecemasan Primigravida Trimester III Di Puskesmas Wilayah 
Kota Bukittinggi. Naskah Publikasi. Universitas 'Aisyiyah Yogyakarta

Sibuea, M. D., Tendean, H. M., \& Wagey, F. W. (2013). Persalinan Pada Usia $\geq 35$ Tahun Di Rsu Prof. Dr. RD Kandou Manado. eBiomedik, 1(1).

Schall. (2018). Effects of music intervention during caesarean delivery on anxiety and stress of the mother a controlled, randomised study. BMC Pregnancy Childbirth, 18: 435.

Setyawan. (2013). Intervensi Terapi Musik Relaksasi Dan Suara Alam (Nature
Sound) Terhadap tingkat Nyeri Dan Kecemasan Pasien (Literature Review). Jurnal Ilmu Keperawatan, 1 (8).

Trianingsih. (2015). Faktor-Faktor Yang Berpengaruh Pada Timbulnya Kejadian Placenta Previa. Jurnal Kedokteran Yarsi 23 (2).

Triatna. (2018). Musik Langgam Jawa untuk Menurunkan Kecemasan pada Pasien Pre-Operasi. Jurnal Kesehatan, 9 (2).

Varney, H. (2007). Buku Ajar Asuhan Kebidanan Edisi I. Jakarta. EGC. 